\title{
Messages from the Border: Novel Insights in Signal Transduction Pathways Involved in Tumor Invasion and Metastasis
}

\author{
Michele Ciccarelli', Mariarosaria Rusciano², Daniela Sorriento ${ }^{3}$, Angela Serena Maione², \\ Maria Soprano $^{2}$, Guido Iaccarino ${ }^{1,4}$, Maddalena Illario ${ }^{2 *}$ \\ ${ }^{1}$ Department of Medicine and Surgery, University of Salerno, Salerno, Italy \\ ${ }^{2}$ Department of Clinical and Translational Medicine, Federico II University, Napoli, Italy \\ ${ }^{3}$ IBP, CNR, Napoli, Italy \\ ${ }^{4}$ IOS e Coleman, Napoli, Italy \\ Email: ${ }^{*}$ illario@unina.it
}

Received 7 January 2015; accepted 10 February 2015; published 11 February 2015

Copyright (C) 2015 by authors and Scientific Research Publishing Inc.

This work is licensed under the Creative Commons Attribution International License (CC BY).

http://creativecommons.org/licenses/by/4.0/

\section{(c) (i) Open Access}

\begin{abstract}
Cancer is a multistep process encompassing the transformation of normal epithelial cells to the stromal invasion and metastasis, with these last considered the final stage of the disease. Tumor invasiveness is based on creation of a specific peri-tumoral environment which on turn depends upon epithelial-stromal interactions, degradation of extracellular matrix and reorganization of fibrillar components. Even though several aspects of the stromal and cellular remodeling have been elucidated and described, such as the epithelial-mesenchymal transition (EMT) and extracellular matrix degradation, all the underlying molecular mechanism are far to be elucidated in their complexity. In this review we focused on new actors such as microRNAs, G protein coupled receptor kinases (GRKs) and Calcium/calmodulin-dependent protein kinase (CaMKs) known to be involved in several important physiological processes like development, cell differentiation and cell signaling, and more recently linked to tumor progression and invasion.
\end{abstract}

\section{Keywords}

Metastasis, Angiogenesis, miRNA, GRKs, CaMKs

\section{Introduction}

Etiology and development of the several cancer diseases may differ case by case, but the common mechanism ${ }^{*}$ Corresponding author.

How to cite this paper: Ciccarelli, M., et al. (2015) Messages from the Border: Novel Insights in Signal Transduction Pathways Involved in Tumor Invasion and Metastasis. Journal of Cancer Therapy, 6, 199-212. 
relies on a progressive accumulation of mutations of genes designated to control cell growth and proliferation, allowing tumor cells to escape from the strictly roles on which healthy cells depend on and acquiring an undefined and uncontrolled power over the rest of the cellular systems. Thus, cancer can be considered in the most of cases as an acquired genetic disease, where specific classes of gene are involved [1]. Specifically, there are two classes of genes that can control cancer development. Oncogenes and tumor suppressor genes belong to one class, while the other class belongs to the caretaker genes. Tumor suppressor genes are evolved to inhibit deregulated cell growth. Usually cancer formation ensues when activation and inactivation of an oncogene and a tumor suppressor gene, respectively, occur in a cell at the same time. The caretaker genes control the rate of mutation in the genome. A defective caretaker gene would allow accumulation of mutation in the genome and thus leading to a higher rate of tumor formation. Therefore, cancer formation occurs due to functional defects in multiple genes that lead to specific alterations, respect to normal cell physiology. A tumor can be defined by the following features: 1) self-sufficiency in growth signals; 2) insensitivity to growth inhibition; 3) evasion of apoptosis; 4) immortalization; sustained angiogenesis; 5) and tissue invasion and metastasis [2]. Metastasis along with angiogenesis and tissue invasion are the most fatal characteristics of malignancy tumor, which accounted for more than $90 \%$ of tumor-related mortality due to the dissemination and survival in the circulation, and subsequent adhesion and colonization the secondary organ or tissue [3] [4]. The origin of tumor cell, genetic variation, the circulatory mode and the physiological structure of the metastatic organ determines the specific sites of distant metastasis. As an initial step in cancer metastasis, epithelial tumor cells in general disseminate from a primary solid tumor mass and invade into the surrounding stromal tissues. Invasion is enhanced by tumor cell activation of the epithelial-mesenchymal transition (EMT) [5]-[8]. The EMT is characterized by the loss of epithelial apicobasal polarity and cell-cell contacts, modulation of cell-matrix adhesion, enhanced proteolytic activity, cytoskeletal remodeling, and acquisition of the ability to migrate and invade the extracellular matrix (ECM) [5] [7]. During the EMT, epithelial cells undergo molecular changes; epithelial cells gradually lose their epithelial markers, such as E-cadherin, ZO-1, and cytokeratins, and concomitantly acquire mesenchymal markers, such as vimentin, fibronectin, N-cadherin, and alpha smooth muscle actin [5] [7]. These steps are promoted by creation of a specific tumor micro-enviroment, a complex network of intricate tumour-stroma interactions involving integrin-dependent adhesion and cell migration on the ECM, ECM degradation by matrix metalloproteinases (MMPs), and activation of signaling pathways responsible for cell survival, proliferation and motility, triggered by growth factor receptors activated by the environment [7] [8]. In theory, the metastatic lesion is originated from their primary tumor, so they should have the same molecular profile with the primary tumor. But this view has been recently modified. Indeed, molecular mechanisms of tumor progression and invasion can differ among tumors of different origin but also within the same disease according to its evolving nature and the progressive accumulation of gene mutation and molecular alterations [9]. Thus, it is not surprising that specific molecular alterations have been identified in different tumors, and their weight may also differ according to specific stage of the disease, opening to a more tailored therapy for patients, based on the genetic and molecular characteristics of the tumor. Hereby, we will describe the latest discoveries on molecular mechanisms involved in tumor progression and invasion, with particular attention on phenomenon involved in EMT transition and tumor micro-enviroment.

\section{Role of microRNA in Cancer Cell Biology}

MicroRNAs (miRNAs) are endogenous small ( 22 nucleotides long) non-coding RNAs that mostly negatively regulate gene expression by base pairing within the 3'-untranslated region of target messenger RNAs (mRNA). miRNAs have been well described as regulators of many biological processes and recent advances in cancer biology have emerged their important roles in regulating tumor responses [10]-[12].

The tight relationship between cancer and miRNAs is witnessed by the evidence that numerous transcription factors, some of them well characterized tumor suppressors or oncogenes, regulate miRNA transcription. Transcription factors of coding genes like Myc and p53, as well as cell type-specific transcription factors such as MEF2, PU.1, and REST promotes or inhibit miRNAs transcription [13] [14]. Furthermore, growth factor stimuli such as PDGF, TGF-b and BDNF trigger pri-miRNA transcription in specific cellular context [15]-[17]. Myc had been deeply investigated as a miRNA transcriptional regulator and was found to be promoter of some oncogenic miRNAs as well as the transcriptional inhibitor of tumor suppressor miRNAs [18] [19]. One of the first documented oncogenic miRNA clusters promoted by Myc is miR-17 - 92, which is frequently over-expressed in a variety of 
tumors like B-cell lymphomas, breast, colon, lung, pancreas, prostate, and stomach cancers [20] [21]. Some other tumorigenic miRNAs induced by Myc are miR-19a/b, implicated in cancer metabolism and cancer cell survival, 46 miR-18a which contributes to angiogenesis [22] and miR-9 which modulates the expression of mediators of metastasis [23]. Contemporarily, Myc can also actively repress the transcription of numerous miRNAs, including some members of the let-7 and miR-29 families, as well as miR-15a/16-1, miR-26a and miR-34a [19]. These miRNAs have been related to antiproliferative, proapoptotic and antitumorigenic activities in different tumors [24] [25].

Recent studies have also unveiled the role of the epigenetic modification at miRNA loci during cancer. Aberrant hypermethylation of certain miRNAs (miR-34b, miR-34c, miR-9-1, miR-129-2, and miR-137), which are all located in CpG islands, is associated with their reduced expression in Colon rectal cell lines and cancerous tissues [26]-[28]. Deregulated expression of miRNAs in cancer is also a consequence of alteration in histone marks, which occur primarily due to the aberrant action of histone deacetylases and the Polycomb repressor complex (PRC2). For example, over expression of PRC2 in prostate cancer contributes to the repression of miR101 and miR-205 by increasing the levels of H3K27me3 at their promoters. These alterations result in an increased rate of cell proliferation [29]. Moreover, BRCA1, a well-known tumor suppressor, in addition to its canonical function, can also epigenetically repress the oncomiR miR-155 via its association with HDAC2, which deacetylates histones H2A and H3 on the miR-155 promoter [30].

Functional consequence of altered miRNAs expression on cancer cell phenotype and malignancy can differ according to their different oncogenic or anti-oncogenic role (Table 1). Certain miRNAs, when upregulated, can suppress genes responsible for growth/proliferation inhibition, and downregulation of other specific miRNAs can enhance the expression of genes responsible for growth/proliferation promotion, resulting in either development or progression of cancer. For example, elevated miR-21 levels have been reported in high-grade pancreatic intraepithelial neoplasia lesions [31], whereas high expression of miR-135b was suggested as a pancreatic ductal adenocarcinoma biomarker [32]. Recently, miR-206 has been found as a novel negative regulator of $\mathrm{NF}-\kappa \mathrm{B}$ signaling and, thereby, miR-206 functions as a tumor suppressor by inhibiting tumor growth, cancer cell invasiveness and release of an NF- $\kappa$ B-dependent circuit of pro-angiogenic cytokines and growth factors [33]. Nonetheless, miR-206 has been found to be significantly downregulated in tumors of PDAC patients [34]. In general miRNAs can participate in all metastatic cascades, including angiogenesis, invasion, intravasion, circulation, extravasion and finally metastatic colonization of secondary sites.

\section{3. miRNA and Angiogenesis}

Angiogenesis is defined as the generation of new blood vessels, but while it can be considered fundamental for creation of a supplementary circulation during chronic ischemic disease, in tumor disease leads to creation of aberrant new vessels which promotes growth and facilitates metastasis [35]. Indeed, both primary and secondary

Table 1. Role of specific miRNAs in metastatic processes.

\begin{tabular}{ccc}
\hline MicroRNAs & Target Genes/Pathways & Effects on \\
\hline mir21 & HIF1 $\alpha$-VEGF & Angiogenesis $\Uparrow$ \\
let-7 family, miR-22, miR-101 & P21, P53 and PTEN & Angiogenesis $\Downarrow$ \\
miR-17-92 & GLUT1-2, IGF-2, BNIP-3 & Metabolic shift $\Downarrow$ \\
miR-497 & TSP-1 and CTGF & Angiogenesis $\Uparrow$ \\
miR-200 family & IGF-1R & Angiogenesis $\Downarrow$ \\
Mir-185 & ZEB1/ZEB2 & EMT $\Downarrow$ \\
Mir-23a-24 & STIM-1 & EMT $\Uparrow$ \\
miR-20 & FZD5, TMEM92 & EMT $\Downarrow$ \\
\hline
\end{tabular}

HIF1 $\alpha$ : Hypoxia-inducible factor 1-alpha; VEGF: Vascular Endothelial Growth factor; PTEN: Phosphatase and tensin homolog; GLUT: Glucose Transporter; IGF: Insulin-like growth factor; BNIP: BCL2/adenovirus E1B 19 kd-interacting protein family; TSP1: Thrombospondin 1; CTGF: Connective tissue growth factor; IGF-1R: Insulin-like growth factor 1 (IGF-1) receptor; ZEB: Zinc finger E-box-binding homeobox 1; STIM1: Stromal interaction molecule 1; FZD5: Frizzled-5; TMEM92: Transmembrane protein 92. 
(metastatic) tumor growth at any site are key components of angiogenesis [36] and recent studies indicate that miRNAs may regulate angiogenesis by exerting both pro-angiogenic or anti-angiogenic effects [37] [38]. Interestingly, also the aberrant tumor angiogenesis can lead to the dysregulation of specific miRNAs through tumor hypoxia. This last is usually induced by the inadequate vascularization due to the aberrant tumor angiogenesis and the increase in oxygen diffusion distances due to rapid expansion of tumor cells [39] [40]. Tumor cells usually have a greater capacity to adapt to a hostile, hypoxic environment for survival, compared to normal cells, which contributes to their malignant and aggressive behavior. A large number of miRNAs have been reported to be responsive or associated to hypoxia and HIF signaling in a wide range of cells or tissues (Figure 1). Increased expression of miR-21, for example, has been observed in several tumors and its expression is promoted by hypoxia in cancer breast cells under hypoxic conditions [41] [42]. Over-expression of miR-21 in DU145 cells increases the expression of HIF- $1 \alpha$ and VEGF and increases tumor angiogenesis through inhibition of PTEN, a known tumor suppressor in cancers acting by down-regulation of HIF-1 $\alpha$ and VEGF [43]. Thus, HIF-1 $\alpha$ is a key downstream target of miR-21 in the regulation of tumor angiogenesis. It has also been shown that over-expression of miR-21 could promote the survival in bone marrow mesenchymal stem cells under hypoxic condition. Down-regulation of miR-21 increase apoptosis of mesenchymal stem cells [44]. Inversely, several miRNAs, such as let-7 family, miR-22 and miR-101 have shown anti-angiogenesis and tumor-suppressor properties by targeting P21, P53 and PTEN [45]-[48]. Nonetheless, they are downregulated in hypoxic conditions in various cancer cell lines such as colon cancer, liver cancer, ovarian cancer, and ER+ breast cancer cells [49]-[52] (Figure 1).

miRNAs can regulate invasion and metastasis by targeting the transcripts of various genes involved in the EMT event, including EMT-inducing transcription factors. For example, members of the miR-200 family are negative regulators of the EMT and are essential for maintenance of the epithelial status through the downregulation of ZEB1 and ZEB2. In turn, miR-200 members are transcriptionally repressed by ZEB1 and ZEB2, thus establishing a double-negative feedback loop [53]. Instead, miR-185 has been recently discovered to promote CRC metastasis by targeting STIM1 (stromal interaction molecule 1), an endoplasmic reticulum $\mathrm{Ca}^{2+}$ sensor that $^{2+}$ triggers the store-operated $\mathrm{Ca}^{2+}$ entry activation and involved in EMT while miR-23a-24 overexpression leads to gene silencing of FZD5, TMEM92 and/or HNF1B with following reduced expression and degradation of Ecadherin and $\beta$-catenin and altered expression of Wnt-related genes [54].

\section{Role of Adrenergic System in Cancer Progression and Invasion}

Adrenergic system is pivotal for promoting angiogenesis and this is evident in pathological conditions as chronic ischemia where endogenous catecholamine can activate both endothelial $\alpha_{1}$ and $\beta_{2} \mathrm{AR}$ with opposite effects on endothelial cell proliferation, migration and survival. Besides the potential clinical and therapeutic application in cardiovascular disease, in particular during chronic ischemia, it is not surprising that these discoveries can be applied also in oncology. The connection between adrenergic system and tumor progression has been evidenced

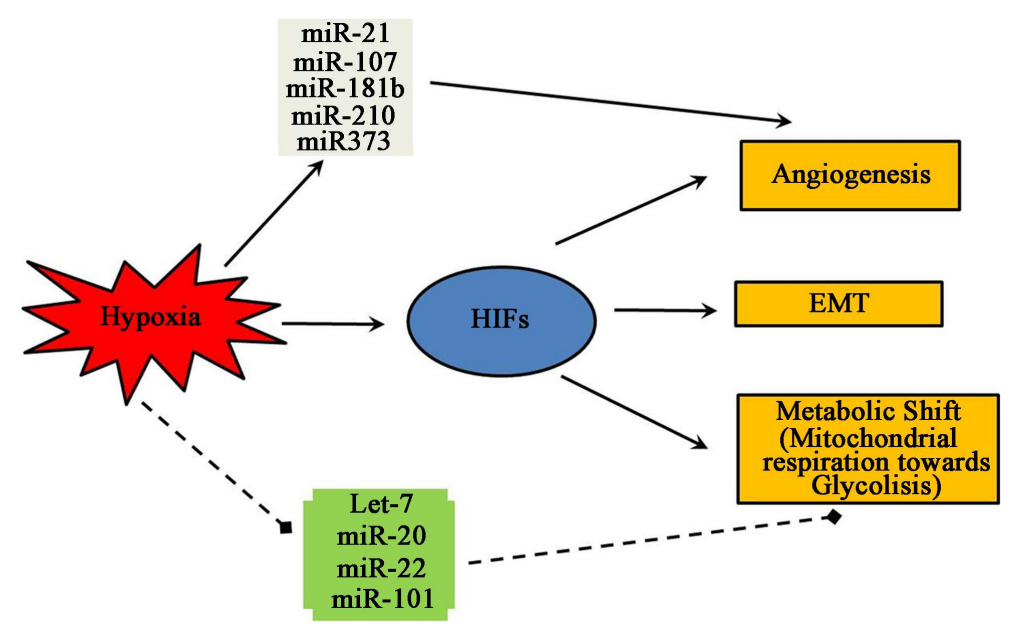

Figure 1. Hypoxia induced and repressed expressions of miRNAs (Continuous line: activation; Dotted line: inhibition). 
in stress condition where the stress derived from social isolation was found to elevate the tumor noradrenaline level in ovarian cancer patients, and its level was correlated with tumor grades and stages [55]. In particular, pancreatic, breast, ovarian and colorectal cancers have been extensively investigated about the effects of $\beta$-adrenoceptor system in preclinical and clinical settings [56] [57]. The study from Thaker and colleagues [56] revealed that chronic stress could elevate the tumour noradrenaline level in an orthotopic ovarian cancer in a mouse model and obviously increased tumour burden and aggressiveness of tumour growth. Propranolol, a nonselective $\beta \mathrm{AR}$ antagonist, completely abolished the effects of chronic stress on tumour growth. In contrast terbutaline, a $\beta_{2} \mathrm{AR}$ agonist produced a similar increase in tumour weight just like under chronic stress. Even molecular mechanisms are not completely understood, study in prostate and breast cancer cells also demonstrated that adrenaline stimulation reduced the sensitivity of cancer cells to apoptosis through $\beta_{2} \mathrm{ARs} /$ protein kinase A (PKA)/inactivation of proapoptotic protein BCL2-associated death promoter (BAD) [58]. Preclinical model further confirmed that stress hormone like adrenaline promoted prostate carcinogenesis through inhibition of apoptosis and tumor involution mediated by an adrenaline $\beta_{2} \mathrm{AR} / \mathrm{PKA} / \mathrm{BAD}$ antiapoptotic signalling pathway [59]. Moreover, adrenaline and noradrenaline can induce proliferation of colorectal cancer cells preferentially through the $\beta_{2} \mathrm{AR}$ [60] [61].

\section{Adrenergic Receptors and Angiogenesis}

Besides the effects on cancer cell proliferation adrenergic system can intervene also in promoting angionenesis, which is known to be essential for tumor growth and metastasis. Several cancer models have proven that adrenaline and noradrenline could upregulate the expression of VEGF and induce tumour angiogenesis and aggressive growth [56] [62]-[64]. Besides VEGF, other angiogenic factors such as interleukin 6 (IL-6), IL-8, matrix metalloproteinase (MMP)-2 and MMP-9 could be elevated by the stimulation of adrenaline and noradrenaline in a diversity of cancer cells via $\beta$ AR signaling [56] [64] [65]. Therefore, administration of $\beta$ AR antagonist like propranolol could completely abrogate the secretion of these factors and their mediated functions, implying that $\beta$ blockers have potential therapeutic value for the management of relevant cancers. This hypothesis is supported by in vivo models of proliferative retinopathies which showed a strong inhibitory role against vascular changes exerted by the blockade of specific $\beta$ ARs. In particular, the $\beta_{2}$ AR seems to be the mostly involved in these responses, and the $\beta_{1} / \beta_{2}$ AR blocker propranolol results highly effective in inhibiting both the increase of VEGF expression caused by a hypoxic insult and the consequent neovascular response. These observations have prompted clinical trials in preterm infants with retinopathy (ROP), where oral administrations of propranolol produced positive results in terms of efficacy, although safety problems were also reported [66]. A counterregulatory system appears to be in place, since $\alpha_{1}$ adrenergic receptos are negative regulators of angiogenesis. Thus, it is possible to speculate a fine tuning of $\alpha_{1}$ and $\beta_{2}$ AR stimulation can be involved in tumor angiogenesis [67] [68]. Such a suggestive hypothesis is also supported by the recent acquisistion that EC can release catechoilamines under hypoxic conditions, thus regulating in a paracrine manner angiogenesis [69].

\section{GRKs and Tumor Growth}

Connected to the role of the adrenergic system in tumorgenesis, G protein-coupled receptor kinases (GRKs) are a versatile family of kinases that play a critical role in $G$ protein-coupled receptor homologous desensitization, including adrenergic receptors. GRKs phosphorylate specific serine and threonine residues in the cytoplasmic domains of the activated receptor, thereby promoting receptor-arrestin interaction and uncoupling of the receptor from its G protein [70]. The GRK family consists of seven members (GRK1-7) with differing patterns of expression. GRK1 and GRK7 are restricted to the visual system; GRK4 is found predominantly in the testis, whereas GRK2, GRK3, GRK5, and GRK6 are expressed in all mammalian cells [70] [71]. Although all GRKs have similar structural organization, they differ in their mechanisms of activation [71] [72]. GRK2 and GRK3 are pleckstrin homology domain - containing proteins, which on receptor activation are recruited to the membrane by G $\beta \gamma$ [73]-[75]. GRK4, GRK5, and GRK6, however, are membrane-associated proteins and are directly activated by the receptor-ligand complex [76]-[78].

Besides their inhibitory role in GPCR signalling, recent and emerging evidence indicate that both GRKs are able to interact with a variety of cellular proteins involved in signal transduction, thus contributing to signal propagation at defined cellular locations upon GPCR activation [79]. Moreover, GRKs are able to modulate specific cellular functions including cell cycle progression and proliferation, migration, angiogenesis and metabol- 
ism [67] [80]-[83].

GRK2 has recently demonstrated to promote down-regulation via $\beta$-Arrestin 1 of CXC chemokine receptor 4 (CXCR4), a G protein-coupled receptor (GPCR) located on the cell surface that signals upon binding the chemokine stromal derived factor-1 (SDF-1) in the related SH-SY5Y and SK-N-SH human neuroblastoma cell lines, thus potentially influencing the CXCR4-driven metastasis of neuroblastoma [84].

GRK2 protein also plays a critical role in driving cell progression through G1/S and G2/M transitions in a kinase-dependent and independent manner. GRK2 is part of an intrinsic pathway that ensures timely progression of cell cycle at G2/M by means of its functional interaction with CDK2/cyclinA and Pin1 [81]. Such pathway is disrupted upon DNA damage, when GRK2 appears to turn into a pro-arresting factor that promotes increased cell survival and to dampen p53-dependent responses by mechanisms that remain to be establish. On the other hand, GRK2 contributes to the Hedgehog/Smoothened-triggered control of cell proliferation by promoting Smo activity and relieving the patched-dependent inhibition of cyclin B [85]. Mice with selective endothelial reduction of GRK2 have shown marked vascular alterations with inflammatory injury and a defective angiogenesis [86] [87], characterized by a lack of functional vessels, concomitant with the occurrence of aberrant vessel-like structures with a poor mural coverage. Notably, this transformed environment is also associated to a decreased GRK2 expression in human breast cancer vessels [87].

GRK5 regulates the activity of the transcription factor $\mathrm{NF} \kappa \mathrm{B}$ [88]. In particular, in endothelial cells GRK5 is able to bind the inhibitory protein of $\mathrm{NF} \kappa \mathrm{B}, \mathrm{I} \kappa \mathrm{B} \alpha$, by means of the RH domain (GRK5-RH) and stabilize the complex $\mathrm{I} \kappa \mathrm{B} \alpha / \mathrm{NF} \kappa \mathrm{B}$ in the nucleus, thus inhibiting $\mathrm{NF} \kappa \mathrm{B}$ transcriptional activity [88]. Indeed, RH overexpression, which causes GRK5-I $\kappa \mathrm{B} \alpha$ interaction, inhibits the transcriptional activity and DNA binding of NF $\kappa \mathrm{B}$ both in basal condition and after stimulation with LPS. Accordingly, GRK5-RH has demonstrated to counteract tumors development in BALB/c nude mice, grown after subcutaneous injection of KAT-4 cells [89]. GRK5 appears also to be directly involved in tumor growth. GRK5 is highly expressed in the aggressive prostate cancer PC3 cell line and its silencing by RNA interference attenuated in vitro cell proliferation and tumor growth in mice [90]. GRK5 knockdown leads to G2/M arrest in the cell cycle, with decreased cyclin D1 expression, Rb protein phosphorylation and E2F target gene expression involved in cell cycle control [91] [92]. Furthermore, GRK5 phosphorylates and inhibits p53 mediated apoptosis in cultured osteosarcoma cells and in mice [93].

GRK6 levels have been found to be positively correlated with clinical and pathological features of human hepatocarcinoma [94]. This kinase is downregulated in Medulloblastoma (MB), relative to other GRKs, while the percentage of GRK6 expression is lower in MB tumors with metastasis (22\%), compared to those without metastasis (43\%) [95]. At molecular level, GRK6 has been described to act as a negative regulator of CXCR4 signaling and, thus, as inhibitor of the cellular migration [95]. More recently, GRK6 has been shown to participate in the complex setting of tumor environment through multiple mechanisms. Deletion of GRK6 in mice increases the activity of the host CXCR2, resulting in greater PMN infiltration and MMP release in the tumor microenvironment, thereby promoting angiogenesis and metastasis [96] [97].

\section{CaMKs Signalling in Progression of Cancer}

Calcium/calmodulin-dependent protein kinase (CaMKs) are multi-functional serine/threonine protein kinases, activated by intracellular calcium changes. CaMKs (CaMKI, CaMKII and CaMKIV) have a very similar structure domain that includes an $\mathrm{N}$ terminal kinase domain, an autoregulatory domain, an overlapping CaM-binding domain and, in phosphorylase kinase and CaMKII, a C-terminal association domain that is essential for multimerization and targeting. They are involved in processes that cause tumor progression, including cell cycle regulation, apoptosis and differentiation as well as cancer cell metastasis.

CaMKIV is a monomeric CaMKs that is expressed in subanatomic regions of the central and peripheral nervous system, T lymphocytes, and male germ cells. It is frequently localized to the nucleus, where it serves as a mediator of $\mathrm{Ca}^{2+}$-dependent gene expression [98]. It regulates the activation of different transcription factors, including cyclic adenosine mono phosphate (CAMP) response element binding protein (CREB), activating transcription factor (ATF), serum response factor (SRF), and transcriptional co-factors including CREB binding protein (CBP) [99]. CaMKIV plays an important physiological role in cellular differentiation during embryogenesis, since embryonic expression of CaMKIV correlates with periods of differentiation and terminal mitoses [100]. Indeed, CaMKIV is also involved in early hematopoietic development. The absence of CaMKIV results in hematopoietic failure, characterized by a diminished hematopoietic stem KLS cell population (KLS) and by 
an inability of these cells to reconstitute blood cells upon serial transplantation. Furthermore, Camk $4^{-/} / \mathrm{KLS}$ cells display enhanced proliferation as well as increased apoptosis, in vivo and in vitro, compared with wild type (WT) cells and have decreased levels of phospho-CREB (pCREB), CBP, Bcl-2 mRNA and Bcl-2 protein [101]. Less is known about the role of CaMKIV in cancer. CaMKIV mediates the apoptotic effect of compound $\mathrm{K}$ (CK), an intestinal metabolite of ginseng protopanaxadiol saponins in colon cancer cells through AMPK signaling [102]. Moreover, hepatocarcinoma cells of both rat and human origin express higher level of CaMKK and CaMKIV than do normal hepatocytes from the corresponding species [103]. Indeed the presence of CaMKIV correlates with a poor diagnosis in different type of cancer [104] [105].

The most well characterized of the multifunctional CaM kinases is CaMKII [106]. CaMKII is encoded by 4 separate genes $(\alpha, \beta, \gamma$, and $\delta)$, and alternate splicing of these genes produces the 24 polypeptides seen in vivo [106].

It has been demonstrated that in Fas-resistant glioma cell lines CaMKII activity was upregulated and that cellular Fas-associated death domain-like interleukin-1b-converting enzyme-inhibitory protein (c-FLIP) was recruited to the Fas death-inducing signaling complex (DISC) [107]. The inhibition of CaMKII activity leads to a reduction of c-FLIP expression and cells became sensitive to Fas-mediated apoptosis. In another study, inhibition of CaMKII converted melanoma cells from TRAIL-resistant to -sensitive [108]. The effect of CaM-kinase inhibition on cell death induction in the breast carcinoma cell line MCF-7 was investigated in response to oxidative stress induced by hydrogen peroxide (HP), doxorubicin, radiation, and photodynamic therapy. Chemical (KN-93) and molecular (siRNA) inhibition of CaMKII prevented HP-induced activation of the antiapoptotic kinase ERK suggesting a mechanism by which this sensitization occurs [109]. Different isoforms of CaMKII have been identified in human neuroblastoma cells, which are not expressed in their normal counterparts [110]. Accordingly to the authors this could be due to a switch in CaMKII isoform expression, specifically, the CaMKII alpha isoform is turned off and new CaMKII variants appear. It has also recently been shown that CaMKII is constitutively activated in human astrocytes and protects cells from Fas-mediated apoptosis [111]. Inhibition of CaMKII kinase activity inhibits the expression of phosphoprotein enriched astrocytes-15 kDa/phosphoprotein enriched in diabetes (PEA-15/PED) and c-FLIP thus releasing their inhibition of caspase-8 at the DISC. At the same time CaMKII-dependent phosphorylation events can lead to cell death when cells were treated with apoptogenic toxins microcystin, nodularin, and okadaic acid [112].

It is also been demonstrated a role for $\alpha$-CaMKII in the growth and tumorigenicity of human osteosarcoma [113]. $\alpha$-CaMKII is highly expressed in primary osteosarcoma tissue derived from 114 patients and is expressed in varying levels in different human osteosarcoma cell lines (HOS, MG-63, MNNG/HOS and 143B). The genetic deletion of $\alpha$-CaMKII by shRNA in MG-63 and 143B cells resulted in decreased proliferation (50 and $41 \%$ ), migration (22\% and 25\%) and invasion (95\% and 90\%), respectively. The overexpression of $\alpha$-CaMKII in HOS cells resulted in increased proliferation (240\%), migration (640\%) and invasion (10,000\%). Furthermore, $\alpha$-CaMKII deletion in MG-63 cells significantly reduced tumor burden in vivo (65\%), while $\alpha$-CaMKII overexpression resulted in tumor formation in a previously non-tumor forming osteosarcoma cell line (HOS).

CaMKII is also a transducer of the non-canonical Wnt/ $\mathrm{Ca}^{2+}$ signaling and its activity is increased by 8 fold in prostate cancer cells [114]. Confocal and quantitative electron microscopy showed that specific inhibition of CaMKII in cancer cells causes remodeling of the actin cytoskeleton, irregular wound edges and loose intercellular architecture and a 6 and 8 fold increase in the frequency and length of filopodia, respectively. Conversely, untreated normal prostate cells showed an irregular wound edge and loose intercellular architecture. Live cell imaging showed that a functional consequence of CaMKII inhibition was $80 \%$ decrease in wound healing capacity and reduced cell motility in cancer cells. Furthermore prostate cancer cells express three CaMKII genes: $\beta$, $\gamma$ and $\delta$ and the expression of these genes is under the control of Androgen Receptor (AR) activity. Overexpression of CaMKII genes resulted in resistance to apoptosis induced by KN-93, a CaMKII inhibitor, or wortmanninn, a PI3K/Akt inhibitor, in combination with doxorubicin, thapsigargin and TRAIL. Moreover, overexpression of CaMKII increased DHT-dependent secretion of prostate-specific antigen (PSA) and cell growth of LNCaP in steroid-free condition (SFC). Remarkably, KN-93 was a much more potent inducer of cell death than wortmannin when LNCaP was treated in SFC [115].

CaMKII is also involved in cancer cell metastasis. The overexpression of H282R (constitutively active CaMKII) enhanced gastric cancer cell migration and invasion, and the inhibition of CaMKII activity by KN-62 decreased gastric cancer cell metastasis. Furthermore, H282R upregulated matrix metalloproteinase-9 (MMP-9) expression and production, which were dependent on CaMKII-mediated increase in nuclear factor (NF)- $\kappa \mathrm{B}$ and Akt activation. Finally, CaMKII activation, through phosphorylation of the Thr 286 site, was significantly in- 
creased in the metastatic gastric cancer tissues compared with non-metastatic tissues, suggesting that CaMKII has an important function in the regulation of gastric cancer cell metastasis [116].

CaMKII is also implicated in the control of papillary thyroid carcinoma proliferation [117].

Inhibition of CaMKII attenuated Erk activation and DNA synthesis in thyroid papillary carcinoma (TPC-1), a cell line harboring RET/PTC-1, suggesting that CaMKII is a component of the Erk signal cascade in this cell line

Finally, Si et al. described a biochemical/functional interaction between the $\mathrm{Ca}^{2+} /$ calmodulin-dependent protein kinases (CaMKs) and RARs that modulates the differentiation of myeloid leukemia cells [118]. They observed that CaMKII $\gamma$ is the CaMK that is predominantly expressed in myeloid cells. CaMKII inhibits RAR transcriptional activity, and this enzyme directly interacts with RAR through a CaMKII LxxLL binding motif. CaMKII $\gamma$ phosphorylates RAR $\alpha$ both in vitro and in vivo, and this phosphorylation inhibits RAR $\alpha$ activity by enhancing its interaction with transcriptional corepressors. In myeloid cell lines, CaMKII $\gamma$ localizes to RAR target sites within myeloid gene promoters but dissociates from the promoter upon retinoic acid-induced myeloid cell differentiation. KN62, a pharmacological inhibitor of the CaMKs, enhances the terminal differentiation of myeloid leukemia cell lines, and this is associated with a reduction in activated (autophosphorylated) CaMKII in the terminally differentiating cells. These observations reveal a significant cross-talk between $\mathrm{Ca}^{2+}$ and retinoic acid signaling pathways that regulates the differentiation of myeloid leukemia cells, and they suggest that CaMKII $\gamma$ may provide a new therapeutic target for the treatment of certain human myeloid leukemias. More recently Gu et al. identified CaMKII $\gamma$ as a specific and critical target of berbamine for its antileukemia activity [119]. Berbamine specifically binds to the ATP-binding pocket of CaMKII $\gamma$, inhibits its phosphorylation and triggers apoptosis of leukemia cells. More importantly, CaMKII $\gamma$ is highly activated in LSCs but not in normal hematopoietic stem cells and coactivates LSC-related $\beta$-catenin and Stat3 signaling networks. The identification of CaMKII $\gamma$ as a specific target of berbamine and as a critical molecular switch regulating multiple LSC-related signaling pathways can explain the unique antileukemia activity of berbamine. These findings also suggest that berbamine may be the first ATP-competitive inhibitor of CaMKII $\gamma$, and potentially, can serve as a new type of molecular targeted agent through inhibition of the CaMKII $\gamma$ activity for treatment of leukemia.

Finally, Monaco et al. revealed a new mechanism of regulation between CaMKII and CaMKIV that controls leukemia cells proliferation [120]. They report that inhibition of CaMKII activity results in an upregulation of CaMKIV mRNA and protein in leukemia cell lines. Conversely, expression of CaMKIV inhibits autophosphorylation and activation of CaMKII, and elicits G0/G1cell cycle arrest, impairing cell proliferation. Furthermore, U937 cells expressing CaMKIV show elevated levels of Cdk inhibitors p27kip1 and p16ink4a and reduced levels of cyclins A, B1 and D1. The relationship between CaMKII and CaMKIV is also observed in primary acute myeloid leukemia (AML) cells, and it correlates with their immunophenotypic profile. Indeed, immature MO/M1 AML showed increased CaMKIV expression and decreased pCaMKII, whereas highly differentiated M4/M5 AML showed decreased CaMKIV expression and increased pCaMKII levels. A further mechanism of regulating endothelial cell proliferatin by CaMKII has been recently unveiled, which appear to be a promising target for cancer treatment. Indeed, CaMKII inhibition results in inhibition of phosphatases, with a concomitant increased signaling on ERK pathway. This leads to uncontrolled endothelial cell proliferation, with possible enhanced immature angiogenesis [121].

\section{Conclusion}

The discovery of novel mechanisms of signal transduction in tumors offers new levels of interventions. Cancer therapy has always being leading the field of innovative treatments and has recently developed personalized strategies that are based on the intimate nature of the mechanisms of the disease. The finding of new insights on cancer biology and signal transduction pathways involved offers the possibility to develop new molecular tools for the treatment of cancer. Indeed, the use of anti-miRNA, as well as novel peptides that inhibit GRKs or CaMKII is an anticancer strategy that is actively pursued at the preclinical level, with promising results. Therefore, messages from the research front are positive and full of promises that need to be proved in the clinical realm.

\section{References}

[1] Stein, C.J. and Colditz, G.A. (2004) Modifiable Risk Factors for Cancer. British Journal of Cancer, 90, 299-303. 
http://dx.doi.org/10.1038/sj.bjc.6601509

[2] Hanahan, D. and Weinberg, R.A. (2000) The Hallmarks of Cancer. Cell, 100, 57-70. http://dx.doi.org/10.1016/S0092-8674(00)81683-9

[3] Grothey, A. and Schmoll, H.J. (2001) New Chemotherapy Approaches in Colorectal Cancer. Current Opinion in Oncology, 13, 275-286. http://dx.doi.org/10.1097/00001622-200107000-00011

[4] Fidler, I.J. (2003) The Pathogenesis of Cancer Metastasis: The "Seed and Soil” Hypothesis Revisited. Nature Reviews Cancer, 3, 453-458. http://dx.doi.org/10.1038/nrc1098

[5] Kalluri, R. (2009) EMT: When Epithelial Cells Decide to Become Mesenchymal-Like Cells. The Journal of Clinical Investigation, 119, 1417-1419. http://dx.doi.org/10.1172/JCI39675

[6] Thiery, J.P., Acloque, H., Huang, R.Y. and Nieto, M.A. (2009) Epithelial-Mesenchymal Transitions in Development and Disease. Cell, 139, 871-890. http://dx.doi.org/10.1016/j.cell.2009.11.007

[7] Thiery, J.P. and Sleeman, J.P. (2006) Complex Networks Orchestrate Epithelial-Mesenchymal Transitions. Nature Reviews Molecular Cell Biology, 7, 131-142. http://dx.doi.org/10.1038/nrm1835

[8] Yang, J. and Weinberg, R.A. (2008) Epithelial-Mesenchymal Transition: At the Crossroads of Development and Tumor Metastasis. Developmental Cell, 14, 818-829. http://dx.doi.org/10.1016/j.devcel.2008.05.009

[9] Stahel, R., Bogaerts, J., Ciardiello, F., et al. (2014) Optimising Translational Oncology in Clinical Practice: Strategies to Accelerate Progress in Drug Development. Cancer Treatment Reviews, 41, 129-135.

[10] Garzon, R., Fabbri, M., Cimmino, A., et al. (2006) MicroRNA Expression and Function in Cancer. Trends in Molecular Medicine, 12, 580-587. http://dx.doi.org/10.1016/j.molmed.2006.10.006

[11] DeSano, J.T. and Xu, L. (2009) A Regulation of Cancer Stem Cells and Therapeutic Implications. The AAPS Journal, 11, 682-692. http://dx.doi.org/10.1208/s12248-009-9147-7

[12] Perera, R.J. and Ray, A. (2007) MicroRNAs in the Search for Understanding Human Diseases. BioDrugs, 21, 97-104. http://dx.doi.org/10.2165/00063030-200721020-00004

[13] He, L., He, X., Lim, L.P., et al. (2007) A msicroRNA Component of the p53 Tumour Suppressor Network. Nature, 447, 1130-1134. http://dx.doi.org/10.1038/nature05939

[14] Davis, B.N. and Hata, A. (2009) Regulation of MicroRNA Biogenesis: A miRiad of Mechanisms. Cell Communication \& Signal, 7, 18. http://dx.doi.org/10.1186/1478-811X-7-18

[15] Davis, B.N., Hilyard, A.C., Nguyen, P.H., et al. (2009) Induction of Microrna-221 by Platelet-Derived Growth Factor Signaling Is Critical for Modulation of Vascular Smooth Muscle Phenotype. The Journal of Biological Chemistry, 284, 3728-3738. http://dx.doi.org/10.1074/jbc.M808788200

[16] Shao, M., Rossi, S., Chelladurai, B., et al. (2011) PDGF Induced microRNA Alterations in Cancer Cells. Nucleic Acids Research, 39, 4035-4047. http://dx.doi.org/10.1093/nar/gkq1305

[17] Butz, H., Racz, K., Hunyady, L. and Patocs, A. (2012) Crosstalk between TGF- $\beta$ Signaling and the MicroRNA Machinery. Trends in Pharmacological Sciences, 33, 382-393. http://dx.doi.org/10.1016/j.tips.2012.04.003

[18] Bui, T.V. and Mendell, J.T. (2010) Myc: Maestro of MicroRNAs. Genes \& Cancer, 1, 568-575. http://dx.doi.org/10.1177/1947601910377491

[19] Chang, T.C., Yu, D., Lee, Y.S., et al. (2008) Widespread microRNA Repression by Myc Contributes to Tumorigenesis. Nature Genetics, 40, 43-50. http://dx.doi.org/10.1038/ng.2007.30

[20] He, L., Thomson, J.M., Hemann, M.T., et al. (2005) A microRNA Polycistron as a Potential Human Oncogene. Nature, 435, 828-833. http://dx.doi.org/10.1038/nature03552

[21] Yu, G., Tang, J.Q., Tian, M.L., et al. (2012) Prognostic Values of the miR-17-92 Cluster and Its Paralogs in Colon Cancer. Journal of Surgical Oncology, 106, 232-237. http://dx.doi.org/10.1002/jso.22138

[22] Dews, M., Homayouni, A., Yu, D., et al. (2006) Augmentation of Tumor Angiogenesis by a Myc-Activated MicroRNA Cluster. Nature Genetics, 38, 1060-1065. http://dx.doi.org/10.1038/ng1855

[23] Ma, L., Young, J., Prabhala, H., et al. (2010) miR-9, a MYC/MYCN-Activated microRNA, Regulates E-Cadherin and Cancer Metastasis. Nature Cell Biology, 12, 247-256.

[24] Klein, U., Lia, M., Crespo, M., et al. (2010) The DLEU2/miR-15a/16-1 Cluster Controls B Cell Proliferation and Its Deletion Leads to Chronic Lymphocytic Leukemia. Cancer Cell, 17, 28-40. http://dx.doi.org/10.1016/j.ccr.2009.11.019

[25] Linsley, P.S., Schelter, J., Burchard, J., et al. (2007) Transcripts Targeted by The MicroRNA-16 Family Cooperatively Regulate Cell Cycle Progression. Molecular and Cellular Biology, 27, 2240-2252. http://dx.doi.org/10.1128/MCB.02005-06

[26] Bandres, E., Agirre, X., Bitarte, N., et al. (2009) Epigenetic Regulation of microRNA Expression in Colorectal Cancer. 
International Journal of Cancer, 125, 2737-2743. http://dx.doi.org/10.1002/ijc.24638

[27] Toyota, M., Suzuki, H., Sasaki, Y., et al. (2008) Epigenetic Silencing of MicroRNA-34b/c and B-Cell Translocation Gene 4 Is Associated With CpG Island Methylation in Colorectal Cancer. Cancer Research, 68, 4123-4132. http://dx.doi.org/10.1158/0008-5472.CAN-08-0325

[28] Vogt, M., Munding, J., Gruner, M., et al. (2011) Frequent Concomitant Inactivation of miR-34a and miR-34b/c by CpG Methylation in Colorectal, Pancreatic, Mammary, Ovarian, Urothelial, and Renal Cell Carcinomas and Soft Tissue Sarcomas. Virchows Archive, 458, 313-322. http://dx.doi.org/10.1007/s00428-010-1030-5

[29] Goel, A. and Boland, C.R. (2012) Epigenetics of Colorectal Cancer. Gastroenterology, 143, 1442-1460.

[30] Chang, S., Wang, R.H., Akagi, K., et al. (2011) Tumor Suppressor BRCA1 Epigenetically Controls Oncogenic MicroRNA-155. Nature Medicine, 17, 1275-1282. http://dx.doi.org/10.1038/nm.2459

[31] Du Rieu, M.C., Torrisani, J., Selves, J., et al. (2010) MicroRNA-21 Is Induced Early in Pancreatic Ductal Adenocarcinoma Precursor Lesions. Clinical Chemistry, 56, 603-612. http://dx.doi.org/10.1373/clinchem.2009.137364

[32] Munding, J.B., Adai, A.T., Maghnouj, A., et al. (2012) Global microRNA Expression Profiling of Microdissected Tissues Identifies miR-135b as a Novel Biomarker for Pancreatic Ductal Adenocarcinoma. International Journal of Cancer, 131, 86-95. http://dx.doi.org/10.1002/ijc.26466

[33] Georgantas, R.W., Streicher, K., Greenberg, S.A., et al. (2014) Inhibition of Myogenic MicroRNAs 1, 133, and 206 by Inflammatory Cytokines Links Inflammation and Muscle Degeneration in Adult Inflammatory Myopathies. Arthritis \& Rheumatology, 66, 1022-1033. http://dx.doi.org/10.1002/art.38292

[34] Keklikoglou, I., Hosaka, K., Bender, C., et al. (2014) MicroRNA-206 Functions as a Pleiotropic Modulator of Cell Proliferation, Invasion and Lymphangiogenesis in Pancreatic Adenocarcinoma by Targeting ANXA2 and KRAS Genes. Oncogene, in press. http://dx.doi.org/10.1038/onc.2014.408

[35] Poliseno, L., Tuccoli, A., Mariani, L., et al. (2006) MicroRNAs Modulate the Angiogenic Properties of HUVECs. Blood, 108, 3068-3071. http://dx.doi.org/10.1182/blood-2006-01-012369

[36] Bonauer, A., Carmona, G., Iwasaki, M., et al. (2009) MicroRNA-92a Controls Angiogenesis and Functional Recovery of Ischemic Tissues in Mice. Science, 324, 1710-1713. http://dx.doi.org/10.1126/science.1174381

[37] Bierie, B. and Moses, H.L. (2006) Tumour Microenvironment: TGFbeta: The Molecular Jekyll and Hyde of Cancer. Nature Reviews Cancer, 6, 506-520. http://dx.doi.org/10.1038/nrc1926

[38] Bockhorn, M., Jain, R.K. and Munn, L.L. (2007) Active versus Passive Mechanisms in Metastasis: Do Cancer Cells Crawl into Vessels, or Are They Pushed? The Lancet Oncology, 8, 444-448. http://dx.doi.org/10.1016/S1470-2045(07)70140-7

[39] Favaro, E., Lord, S., Harris, A.L. and Buffa, F.M. (2011) Gene Expression and Hypoxia in Breast Cancer. Genome Medicine, 3, 55. http://dx.doi.org/10.1186/gm271

[40] Denko, N.C. (2008) Hypoxia, HIF1 and Glucose Metabolism in the Solid Tumour. Nature Reviews Cancer, 8, 705-713. http://dx.doi.org/10.1038/nrc2468

[41] Kulshreshtha, R., Ferracin, M., Negrini, M., et al. (2007) Regulation of MicroRNA Expression: The Hypoxic Component. Cell Cycle, 6, 1425-1430. http://dx.doi.org/10.4161/cc.6.12.4410

[42] Kulshreshtha, R., Ferracin, M., Wojcik, S.E., et al. (2007) A MicroRNA Signature of Hypoxia. Molecular and Cellular Biology, 27, 1859-1867. http://dx.doi.org/10.1128/MCB.01395-06

[43] Liu, L.Z., Li, C., Chen, Q., et al. (2011) miR-21 Induced Angiogenesis through AKT and ERK Activation and HIF-1 $\alpha$ Expression. PLOS ONE, 6, e19139. http://dx.doi.org/10.1371/journal.pone.0019139

[44] Nie, Y., Han, B.M., Liu, X.B., et al. (2011) Identification of MicroRNAs Involved in Hypoxia- and Serum Deprivation-Induced Apoptosis in Mesenchymal Stem Cells. International Journal of Biological Sciences, 7, 762-768. http://dx.doi.org/10.7150/ijbs.7.762

[45] Kong, D., Banerjee, S., Ahmad, A., et al. (2010) Epithelial to Mesenchymal Transition Is Mechanistically Linked with Stem Cell Signatures in Prostate Cancer Cells. PLoS ONE, 5, e12445. http://dx.doi.org/10.1371/journal.pone.0012445

[46] Chang, C.J., Hsu, C.C., Chang, C.H., et al. (2011) Let-7d Functions as Novel Regulator of Epithelial-Mesenchymal Transition and Chemoresistant Property in Oral Cancer. Oncology Reports, 26, 1003-1010.

[47] McCarty, M.F. (2012) Metformin May Antagonize Lin28 and/or Lin28B Activity, Thereby Boosting Let-7 Levels and Antagonizing Cancer Progression. Medical Hypotheses, 78, 262-269. http://dx.doi.org/10.1016/j.mehy.2011.10.041

[48] Li, Y., VandenBoom, T.G., Kong, D., et al. (2009) Up-Regulation of miR-200 and Let-7 by Natural Agents Leads to the Reversal of Epithelial-to-Mesenchymal Transition in Gemcitabine-Resistant Pancreatic Cancer Cells. Cancer Research, 69, 6704-6712. http://dx.doi.org/10.1158/0008-5472.CAN-09-1298

[49] Li, J., Zhang, Y., Zhao, J., et al. (2011) Over Expression of miR-22 Reverses Paclitaxel-Induced Chemoresistance 
through Activation of PTEN Signaling in p53-Mutated Colon Cancer Cells. Molecular and Cellular Biochemistry, 357, 31-38. http://dx.doi.org/10.1007/s11010-011-0872-8

[50] Tsuchiya, N., Izumiya, M., Ogata-Kawata, H., et al. (2011) Tumor Suppressor miR-22 Determines p53-Dependent Cellular Fate through Post-Transcriptional Regulation of p21. Cancer Research, 71, 4628-4639. http://dx.doi.org/10.1158/0008-5472.CAN-10-2475

[51] Li, J., Liang, S., Yu, H., et al. (2010) An Inhibitory Effect of miR-22 on Cell Migration and Invasion in Ovarian Cancer. Gynecology Oncology, 119, 543-548. http://dx.doi.org/10.1016/j.ygyno.2010.08.034

[52] Zhang, J., Yang, Y., Yang, T., et al. (2010) MicroRNA-22, Downregulated in Hepatocellular Carcinoma and Correlated with Prognosis, Suppresses Cell Proliferation and Tumourigenicity. British Journal of Cancer, 103, 1215-1220. http://dx.doi.org/10.1038/sj.bjc.6605895

[53] Brabletz, S. and Brabletz, T. (2010) The ZEB/miR-200 Feedback Loop-A Motor of Cellular Plasticity in Development and Cancer? EMBO Reports, 11, 670-677. http://dx.doi.org/10.1038/embor.2010.117

[54] Zhang, Z., Liu, X., Feng, B., et al. (2014) STIM1, a Direct Target of MicroRNA-185, Promotes Tumor Metastasis and Is Associated with Poor Prognosis in Colorectal Cancer. Oncogene, in press.

[55] Lutgendorf, S.K., DeGeest, K., Dahmoush, L., et al. (2011) Social Isolation Is Associated with Elevated Tumor Norepinephrine in Ovarian Carcinoma Patients. Brain, Behavior, and Immunity, 25, 250-255. http://dx.doi.org/10.1016/j.bbi.2010.10.012

[56] Thaker, P.H., Han, L.Y., Kamat, A.A., et al. (2006) Chronic Stress Promotes Tumor Growth and Angiogenesis in a Mouse Model of Ovarian Carcinoma. Nature Medicines, 12, 939-944. http://dx.doi.org/10.1038/nm1447

[57] Schuller, H.M., Al-Wadei, H.A., Ullah, M.F. and Plummer, H.K. (2012) Regulation of Pancreatic Cancer by Neuropsychological Stress Responses: A Novel Target for Intervention. Carcinogenesis, 33, 191-196. http://dx.doi.org/10.1093/carcin/bgr251

[58] Sastry, K.S., Karpova, Y., Prokopovich, S., et al. (2007) Epinephrine Protects Cancer Cells from Apoptosis via Activation of cAMP-Dependent Protein Kinase and BAD Phosphorylation. The Journal of Biological Chemistry, 282, 1409414100. http://dx.doi.org/10.1074/jbc.M611370200

[59] Hassan, S., Karpova, Y., Baiz, D., et al. (2013) Behavioral Stress Accelerates Prostate Cancer Development in Mice. The Journal of Clinical Investigation, 123, 874-886.

[60] Wu, W.K., Wong, H.P., Luo, S.W., et al. (2005) 4-(Methylnitrosamino)-1-(3-pyridyl)-1-butanone from Cigarette Smoke Stimulates Colon Cancer Growth via $\beta$-Adrenoceptors. Cancer Research, 65, 5272-5277. http://dx.doi.org/10.1158/0008-5472.CAN-05-0205

[61] Wong, H.P., Ho, J.W., Koo, M.W., et al. (2011) Effects of Adrenaline in Human Colon Adenocarcinoma HT-29 Cells. Life Science, 88, 1108-1112. http://dx.doi.org/10.1016/j.lfs.2011.04.007

[62] Lee, J.W., Shahzad, M.M., Lin, Y.G., et al. (2009) Surgical Stress Promotes Tumor Growth in Ovarian Carcinoma. Clinical Cancer Research, 15, 2695-2702. http://dx.doi.org/10.1158/1078-0432.CCR-08-2966

[63] Yang, E., Boire, A., Agarwal, A., et al. (2009) Blockade of PAR1 Signaling with Cell-Penetrating Pepducins Inhibits Akt Survival Pathways in Breast Cancer Cells and Suppresses Tumor Survival and Metastasis. Cancer Research, 69, 6223-6231. http://dx.doi.org/10.1158/0008-5472.CAN-09-0187

[64] Yang, E.V., Kim, S.J., Donovan, E.L., et al. (2009) Norepinephrine Upregulates VEGF, IL-8, and IL-6 Expression in Human Melanoma Tumor Cell Lines: Implications for Stress-Related Enhancement of Tumor Progression. Brain, Behavior, and Immunity, 23, 267-275. http://dx.doi.org/10.1016/j.bbi.2008.10.005

[65] Madden, K.S., Szpunar, M.J., Brown, E.B. (2011) $\beta$-Adrenergic Receptors ( $\beta$-AR) Regulate VEGF and IL-6 Production by Divergent Pathways in High $\beta$-AR-Expressing Breast Cancer Cell Lines. Breast Cancer Research and Treatment, 130, 747-758. http://dx.doi.org/10.1007/s10549-011-1348-y

[66] Casini, G., Dal Monte, M., Fornaciari, I., et al. (2014) The $\beta$-Adrenergic System as a Possible New Target for Pharmacologic Treatment of Neovascular Retinal Diseases. Progress in Retinal and Eye Research, 42, 103-129

[67] Ciccarelli, M., Sorriento, D., Cipolletta, E., et al. (2011) Impaired Neoangiogenesis in $\beta(2)$-Adrenoceptor Gene-Deficient Mice: Restoration by Intravascular Human $\beta(2)$-Adrenoceptor Gene Transfer and Role of NFkappaB and CREB Transcription Factors. British Journal of Pharmacology, 162, 712-721. http://dx.doi.org/10.1111/j.1476-5381.2010.01078.x

[68] Ciccarelli, M., Santulli, G., Campanile, A., et al. (2008) Endothelial $\alpha_{1}$-Adrenoceptors Regulate Neo-Angiogenesis. British Journal of Pharmacology, 153, 936-946. http://dx.doi.org/10.1038/sj.bjp.0707637

[69] Sorriento, D., Santulli, G., Del Giudice, C., et al. (2012) Endothelial Cells Are Able to Synthesize and Release Catecholamines Both in Vitro and in Vivo. Hypertension, 60, 129-136.

http://dx.doi.org/10.1161/HYPERTENSIONAHA.111.189605 
[70] Vroon, A., Heijnen, C.J. and Kavelaars, A. (2006) GRKs and Arrestins: Regulators of Migration and Inflammation. Journal of Leukocyte Biology, 80, 1214-1221. http://dx.doi.org/10.1189/jlb.0606373

[71] Reiter, E. and Lefkowitz, R.J. (2006) GRKs and $\beta$-Arrestins: Roles in Receptor Silencing, Trafficking and Signaling. Trends in Endocrinology and Metabolism, 17, 159-165. http://dx.doi.org/10.1016/j.tem.2006.03.008

[72] Pitcher, J.A., Freedman, N.J. and Lefkowitz, R.J. (1998) G Protein-Coupled Receptor Kinases. Annual Review of Biochemistry, 67, 653-692. http://dx.doi.org/10.1146/annurev.biochem.67.1.653

[73] Koch, W.J., Ingles, J., Stone, W.C. and Lefkowitz, R.J. (1993) The Binding Site for the Beta Gamma Subunits of Heterotrimeric G Proteins on the Beta-Adrenergic Receptor Kinase. The Journal of Biological Chemistry, 268, 82568260 .

[74] Luttrell, L.M., van Biesen, T., Hawes, B.E., et al. (1995) G $\beta \gamma$ Subunits Mediate Mitogen-Activated Protein Kinase Activation by the Tyrosine Kinase Insulin-Like Growth Factor 1 Receptor. The Journal of Biological Chemistry, 270, 16495-16498. http://dx.doi.org/10.1074/jbc.270.28.16495

[75] Eichmann, T., Lorenz, K., Hoffmann, M., et al. (2003) The Amino-Terminal Domain of G-Protein-Coupled Receptor Kinase 2 Is a Regulatory G $\beta \gamma$ Binding Site. The Journal of Biological Chemistry, 278, 8052-8057. http://dx.doi.org/10.1074/jbc.M204795200

[76] Premont, R.T., Macrae, A.D., Stoffel, R.H., et al. (1996) Characterization of the G Protein-Coupled Receptor Kinase GRK4. Identification of Four Splice Variants. The Journal of Biological Chemistry, 271, 6403-6410. http://dx.doi.org/10.1074/jbc.271.11.6403

[77] Premont, R.T., Koch, W.J., Inglese, J. and Lefkowitz, R.J. (1994) Identification, Purification, and Characterization of GRK5, a Member of the Family of G Protein-Coupled Receptor Kinases. The Journal of Biological Chemistry, 269, 6832-6841.

[78] Stoffel, R.H., Randall, R.R., Premont, R.T., et al. (1994) Palmitoylation of G Protein-Coupled Receptor Kinase, GRK6. Lipid Modification Diversity in the GRK Family. The Journal of Biological Chemistry, 269, 27791-27794.

[79] Penela, P., Murga, C., Ribas, C., et al. (2010) The Complex G Protein-Coupled Receptor Kinase 2 (GRK2) Interactome Unveils New Physiopathological Targets. The Journal of Biological Chemistry, 160, 821-832. http://dx.doi.org/10.1111/j.1476-5381.2010.00727.x

[80] Ciccarelli, M., Chuprun, J.K., Rengo, G., et al. (2011) G protein-Coupled Receptor Kinase 2 Activity Impairs Cardiac Glucose Uptake and Promotes Insulin Resistance after Myocardial Ischemia. Circulation, 123, 1953-1962. http://dx.doi.org/10.1161/CIRCULATIONAHA.110.988642

[81] Penela, P., Rivas, V., Salcedo, A. and Mayor Jr., F. (2010) G Protein-Coupled Receptor Kinase 2 (GRK2) Modulation and Cell Cycle Progression. Proceedings of the National Academy of Sciences of the United States of America, 107, 1118-1123. http://dx.doi.org/10.1073/pnas.0905778107

[82] Iaccarino, G., Ciccarelli, M., Sorriento, D., et al. (2005) Ischemic Neoangiogenesis Enhanced by $\beta_{2}$-Adrenergic Receptor over Expression: A Novel Role for the Endothelial Adrenergic System. Circulation Research, 97, 1182-1189. http://dx.doi.org/10.1161/01.RES.0000191541.06788.bb

[83] Penela, P., Nogues, L. and Mayor Jr., F. (2014) Role of G Protein-Coupled Receptor Kinases in Cell Migration. Current Opinion in Cell Biology, 27, 10-17. http://dx.doi.org/10.1016/j.ceb.2013.10.005

[84] Clift, I.C., Bamidele, A.O., Rodriguez-Ramirez, C., et al. (2014) $\beta$-Arrestin1 and Distinct CXCR4 Structures Are Required for Stromal Derived Factor-1 to Downregulate CXCR4 Cell-Surface Levels in Neuroblastoma. Molecular Pharmacology, 85, 542-552. http://dx.doi.org/10.1124/mol.113.089714

[85] Jiang, X., Yang, P. and Ma, L. (2009) Kinase Activity-Independent Regulation of Cyclin Pathway by GRK2 Is Essential for Zebrafish Early Development. Proceedings of the National Academy of Sciences of the United States of America, 106, 10183-10188. http://dx.doi.org/10.1073/pnas.0812105106

[86] Ciccarelli, M., Sorriento, D., Franco, A., et al. (2013) Endothelial G Protein-Coupled Receptor Kinase 2 Regulates Vascular Homeostasis through the Control of Free Radical Oxygen Species. Arteriosclerosis, Thrombosis, and Vascular Biology, 33, 2415-2424. http://dx.doi.org/10.1161/ATVBAHA.113.302262

[87] Rivas, V., Carmona, R., Munoz-Chapuli, R., et al. (2013) Developmental and Tumoral Vascularization Is Regulated by G Protein-Coupled Receptor Kinase 2. The Journal of Clinical Investigation, 123, 4714-4730. http://dx.doi.org/10.1172/JCI67333

[88] Sorriento, D., Santulli, G., Fusco, A., et al. (2010) Intracardiac Injection of AdGRK5-NT Reduces Left Ventricular Hypertrophy by Inhibiting NF- $\kappa$ B-Dependent Hypertrophic Gene Expression. Hypertension, 56, 696-704. http://dx.doi.org/10.1161/HYPERTENSIONAHA.110.155960

[89] Sorriento, D., Campanile, A., Santulli, G., et al. (2009) A New Synthetic Protein, TAT-RH, Inhibits Tumor Growth through the Regulation of NFkappaB Activity. Molecular Cancer, 8, 97. http://dx.doi.org/10.1186/1476-4598-8-97

[90] Chakraborty, P.K., Zhang, Y., Coomes, A.S., et al. (2014) G Protein-Coupled Receptor Kinase GRK5 Phosphorylates 
Moesin and Regulates Metastasis in Prostate Cancer. Cancer Research, 74, 3489-3500. http://dx.doi.org/10.1158/0008-5472.CAN-13-2708

[91] Buss, M.C., Remke, M., Lee, J., et al. (2014) The WIP1 Oncogene Promotes Progression and Invasion of Aggressive Medulloblastoma Variants. Oncogene, in press.

[92] Michal, A.M., So, C.H., Beeharry, N., et al. (2012) G Protein-Coupled Receptor Kinase 5 Is Localized to Centrosomes and Regulates Cell Cycle Progression. The Journal of Biological Chemistry, 287, 6928-6940. http://dx.doi.org/10.1074/jbc.M111.298034

[93] Chen, X., Zhu, H., Yuan, M., et al. (2010) G-Protein-Coupled Receptor Kinase 5 Phosphorylates p53 and Inhibits DNA Damage-Induced Apoptosis. The Journal of Biological Chemistry, 285, 12823-12830. http://dx.doi.org/10.1074/jbc.M109.094243

[94] Li, Y.P. (2013) GRK6 Expression in Patients with Hepatocellular Carcinoma. Asian Pacific Journal of Tropical Medicine, 6, 220-223. http://dx.doi.org/10.1016/S1995-7645(13)60027-9

[95] Yuan, L., Zhang, H., Liu, J., et al. (2013) Growth factor receptor-Src-Mediated Suppression of GRK6 Dysregulates CXCR4 Signaling and Promotes Medulloblastoma Migration. Molecular Cancer, 12, 18. http://dx.doi.org/10.1186/1476-4598-12-18

[96] Raghuwanshi, S.K., Smith, N., Rivers, E.J., et al. (2013) G Protein-Coupled Receptor Kinase 6 Deficiency Promotes Angiogenesis, Tumor Progression, and Metastasis. The Journal of Immunology, 190, 5329-5336. http://dx.doi.org/10.4049/jimmunol.1202058

[97] Raghuwanshi, S.K., Su, Y., Singh, V., et al. (2012) The Chemokine Receptors CXCR1 and CXCR2 Couple to Distinct G Protein-Coupled Receptor Kinases to Mediate and Regulate Leukocyte Functions. The Journal of Immunology, 189, 2824-2832. http://dx.doi.org/10.4049/jimmunol.1201114

[98] Hook, S.S. and Means, A.R. (2001) $\mathrm{Ca}^{2+} / \mathrm{CaM-Dependent} \mathrm{Kinases:} \mathrm{From} \mathrm{Activation} \mathrm{to} \mathrm{Function.} \mathrm{Annual} \mathrm{Review} \mathrm{of}$ Pharmacology and Toxicology, 41, 471-505. http://dx.doi.org/10.1146/annurev.pharmtox.41.1.471

[99] Cruzalegui, F.H. and Bading, H. (2000) Calcium-Regulated Protein Kinase Cascades and Their Transcription Factor Targets. Cellular and Molecular Life Sciences CMLS, 57, 402-410. http://dx.doi.org/10.1007/PL00000702

[100] Wang, S.L., Ribar, T.J. and Means, A.R. (2001) Expression of $\mathrm{Ca}^{2+} /$ Calmodulin-Dependent Protein Kinase IV (caMKIV) Messenger RNA during Murine Embryogenesis. Cell Growth \& Differentiation, 12, 351-361.

[101] Kitsos, C.M., Sankar, U., Illario, M., et al. (2005) Calmodulin-Dependent Protein Kinase IV Regulates Hematopoietic Stem Cell Maintenance. The Journal of Biological Chemistry, 280, 33101-33108. http://dx.doi.org/10.1074/jbc.M505208200

[102] Kim Do, Y., Park, M.W., Yuan, H.D., et al. (2009) Compound K Induces Apoptosis via CAMK-IV/AMPK Pathways in HT-29 Colon Cancer Cells. Journal of Agricultural and Food Chemistry, 57, 10573-10578. http://dx.doi.org/10.1021/jf902700h

[103] Tamura, N., Tai, Y., Sugimoto, K., et al. (2000) Enhanced Expression and Activation of $\mathrm{Ca}^{2+} /$ Calmodulin-Dependent Protein Kinase IV in Hepatocellular Carcinoma. Cancer, 89, 1910-1916. http://dx.doi.org/10.1002/1097-0142(20001101)89:9<1910::AID-CNCR6>3.3.CO;2-M

[104] Shang, S., Takai, N., Nishida, M., et al. (2003) CaMKIV Expression Is Associated with Clinical Stage and PCNALabeling Index in Endometrial Carcinoma. International Journal of Molecular Medicine, 11, 181-186.

[105] Takai, N., Miyazaki, T., Nishida, M., et al. (2002) $\mathrm{Ca}^{2+} /$ Calmodulin-Dependent Protein Kinase IV Expression in Epithelial Ovarian Cancer. Cancer Letters, 183, 185-193. http://dx.doi.org/10.1016/S0304-3835(02)00107-6

[106] Braun, A.P. and Schulman, H. (1995) The Multifunctional Calcium/Calmodulin-Dependent Protein Kinase: From Form to Function. Annual Review of Physiology, 57, 417-445. http://dx.doi.org/10.1146/annurev.ph.57.030195.002221

[107] Yang, B.F., Xiao, C., Roa, W.H., et al. (2003) Calcium/Calmodulin-Dependent Protein Kinase II Regulation of c-FLIP Expression and Phosphorylation in Modulation of Fas-Mediated Signaling in Malignant Glioma Cells. The Journal of Biological Chemistry, 278, 7043-7050. http://dx.doi.org/10.1074/jbc.M211278200

[108] Xiao, C., Yang, B.F., Song, J.H., et al. (2005) Inhibition of CaMKII-Mediated c-FLIP Expression Sensitizes Malignant Melanoma Cells to TRAIL-Induced Apoptosis. Experimental Cell Research, 304, 244-255. http://dx.doi.org/10.1016/j.yexcr.2004.11.002

[109] Rodriguez-Mora, O.G., Lahair, M.M., Evans, M.J., et al. (2006) Inhibition of the CaM-Kinases Augments Cell Death in Response to Oxygen Radicals and Oxygen Radical Inducing Cancer Therapies in MCF-7 Human Breast Cancer Cells. Cancer Biology \& Therapy, 5, 1022-1030. http://dx.doi.org/10.4161/cbt.5.8.2910

[110] Tombes, R.M. and Krystal, G.W. (1997) Identification of Novel Human Tumor Cell-Specific CaMK-II Variants. Biochimica et Biophysica Acta (BBA)-Molecular Cell Research, 1355, 281-292. http://dx.doi.org/10.1016/S0167-4889(96)00141-3 
[111] Song, J.H., Bellail, A., Tse, M.C.L., Yong, V.W. and Hao, C.H. (2006) Human Astrocytes Are Resistant to Fas Ligand and Tumor Necrosis Factor-Related Apoptosis-Inducing Ligand-Induced Apoptosis. The Journal of Neuroscience, 26, 3299-3308. http://dx.doi.org/10.1523/JNEUROSCI.5572-05.2006

[112] Fladmark, K.E., Brustugun, O.T., Mellgren, G., et al. (2002) $\mathrm{Ca}^{2+} /$ Calmodulin-Dependent Protein Kinase II Is Required for Microcystin-Induced Apoptosis. The Journal of Biological Chemistry, 277, 2804-2811. http://dx.doi.org/10.1074/jbc.M109049200

[113] Daft, P.G., Yuan, K., Warram, J.M., et al. (2013) Alpha-CaMKII Plays a Critical Role in Determining the Aggressive Behavior of Human Osteosarcoma. Molecular Cancer Research, 11, 349-359. http://dx.doi.org/10.1158/1541-7786.MCR-12-0572

[114] Wang, Q., Symes, A.J., Kane, C.A., et al. (2010) A Novel Role for Wnt/Ca ${ }^{2+}$ Signaling in Actin Cytoskeleton Remodeling and Cell Motility in Prostate Cancer. PLOS ONE, 5, e10456. http://dx.doi.org/10.1371/journal.pone.0010456

[115] Rokhlin, O.W., Taghiyev, A.F., Bayer, K.U., et al. (200) Calcium/Calmodulin-Dependent Kinase II Plays an Important Role in Prostate Cancer Cell Survival. Cancer Biology \& Therapy, 6, 732-742. http://dx.doi.org/10.4161/cbt.6.5.3975

[116] Liu, Z., Han, G., Cao, Y., et al. (2014) Calcium/Calmodulin-Dependent Protein Kinase II Enhances Metastasis of Human Gastric Cancer by Upregulating Nuclear Factor- $\kappa$ B and Akt-Mediated Matrix Metalloproteinase-9 Production. Molecular Medicine Reports, 10, 2459-2464.

[117] Rusciano, M.R., Salzano, M., Monaco, S., et al. (2010) The $\mathrm{Ca}^{2+}$-Calmodulin-Dependent Kinase II Is Activated in Papillary Thyroid Carcinoma (PTC) and Mediates Cell Proliferation Stimulated by RET/PTC. Endocrine-Related Cancer, 17, 113-123. http://dx.doi.org/10.1677/ERC-09-0214

[118] Si, J., Mueller, L. and Collins, S.J. (2007) CaMKII Regulates Retinoic Acid Receptor Transcriptional Activity and the Differentiation of Myeloid Leukemia Cells. The Journal of Clinical Investigation, 117, 1412-1421. http://dx.doi.org/10.1172/JCI30779

[119] Gu, Y., Chen, T., Meng, Z., et al. (2012) CaMKII gamma, a Critical Regulator of CML stem/Progenitor Cells, Is a Target of the Natural Product Berbamine. Blood Journal, 120, 4829-4839. http://dx.doi.org/10.1182/blood-2012-06-434894

[120] Monaco, S., Rusciano, M.R., Maione, A.S., et al. (2015) A Novel Crosstalk between Calcium/Calmodulin Kinases II and IV Regulates Cell Proliferation in Myeloid Leukemia Cells. Cell Signalling, 27, 204-214. http://dx.doi.org/10.1016/j.cellsig.2014.11.007

[121] Ciccarelli, M., Rusciano, M.R., Sorriento, D., et al. (2014) CaMKII Protects MKP-1 from Proteasome Degradation in Endothelial Cells. Cellular Signalling, 26, 2167-2174. http://dx.doi.org/10.1016/j.cellsig.2014.06.009

$\begin{array}{ll}\text { Abbreviations } \\ \text { miRNAs } & \text { microRNAs } \\ \text { GRKs } & \text { G protein coupled receptor kinases } \\ \boldsymbol{\beta} \text { ARs } & \beta \text { adrenergic receptors } \\ \text { CaMKs } & \text { Calmodulin dependent protein kinases } \\ \text { EMT } & \text { Epithelial-mesenchimal transition } \\ \text { CRC } & \text { Colorectal Cancer } \\ \text { MMPs } & \text { Matrix Metallo-proteinases } \\ \text { ECM } & \text { Extracellular Matrix } \\ \text { HDACs } & \text { Histone deacetylases } \\ \text { NF- } \boldsymbol{\kappa} \text { B } & \text { Nuclear factor kappa-light-chain-enhancer of activated B cells } \\ \mathbf{I} \boldsymbol{\kappa} \mathbf{B} \boldsymbol{\alpha} & \text { Nuclear factor of kappa light polypeptide gene enhancer in B-cells inhibitor, alpha }\end{array}$


Scientific Research Publishing (SCIRP) is one of the largest Open Access journal publishers. It is currently publishing more than 200 open access, online, peer-reviewed journals covering a wide range of academic disciplines. SCIRP serves the worldwide academic communities and contributes to the progress and application of science with its publication.

Other selected journals from SCIRP are listed as below. Submit your manuscript to us via either submit@scirp.org or Online Submission Portal.
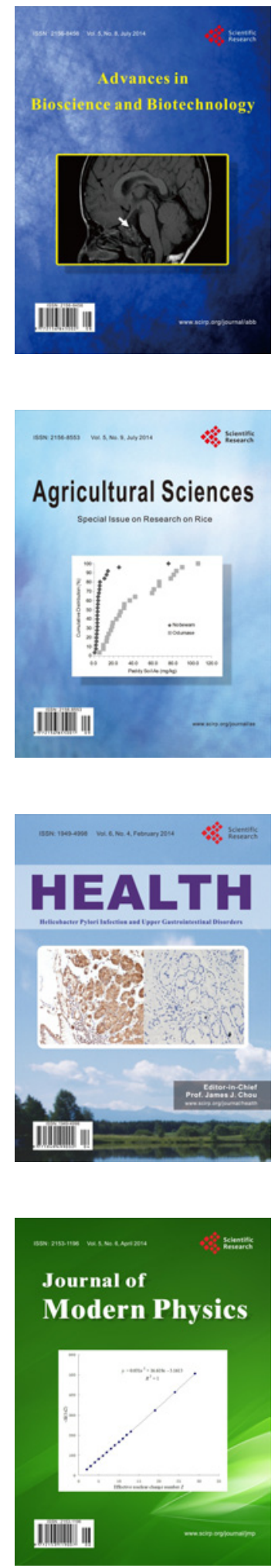
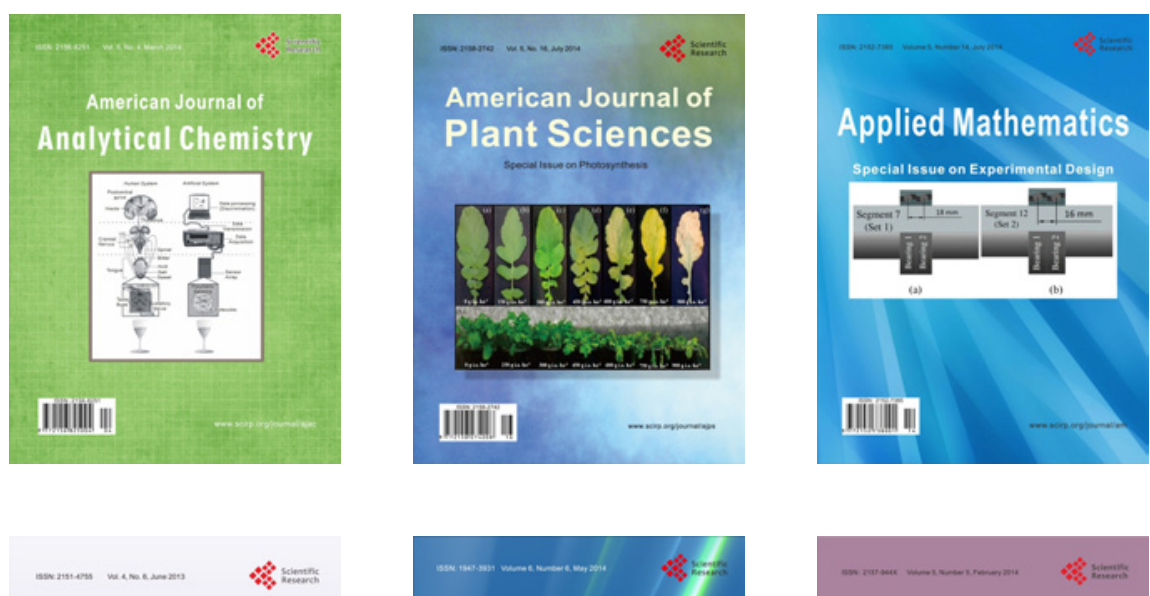

Creative Education
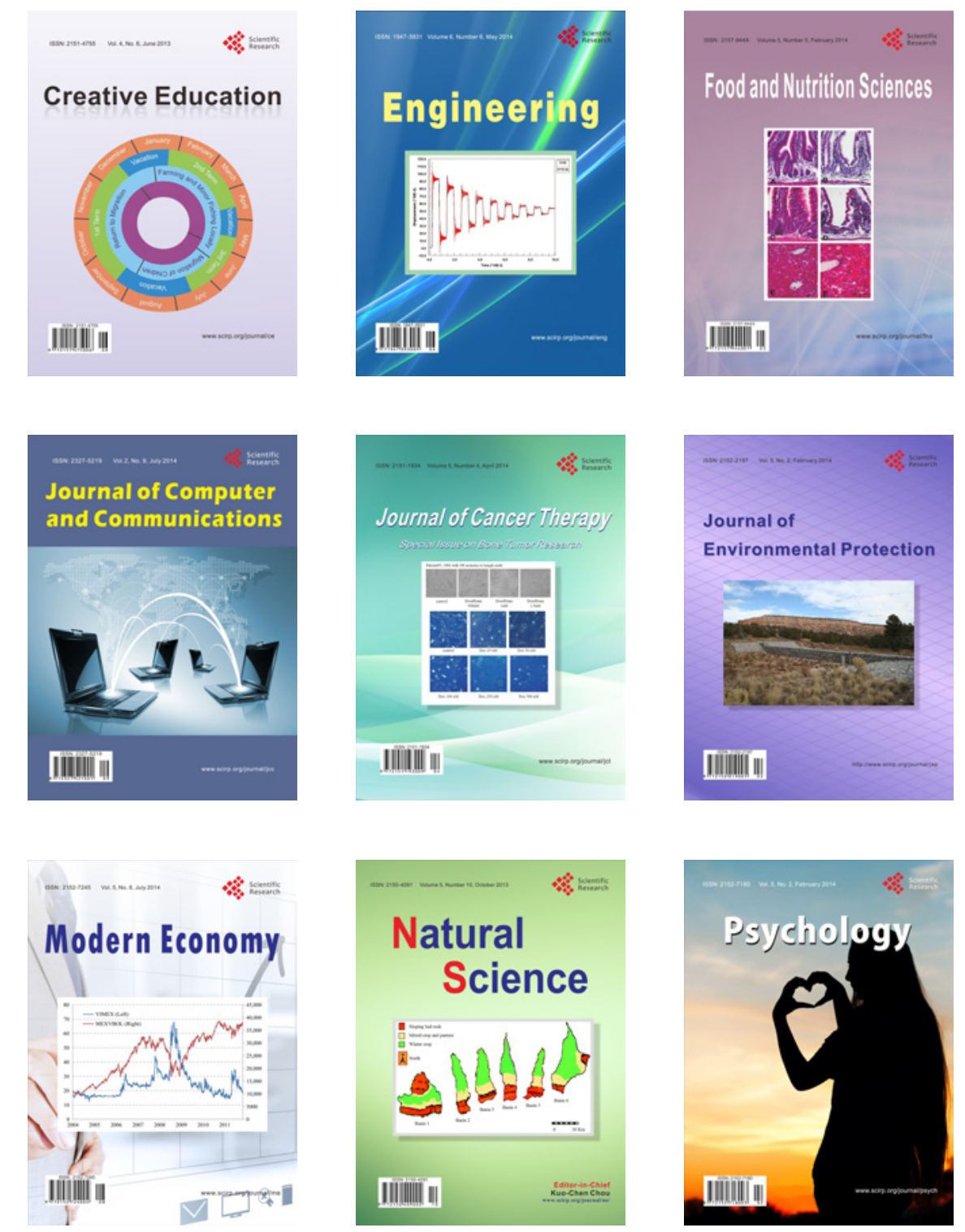